\title{
HIRING AND RETAINING SKILLED EMPLOYEES IN SMES: PROBLEMS IN HUMAN RESOURCE PRACTICES AND LINKS WITH ORGANIZATIONAL SUCCESS
}

\author{
Yuriy BILAN (1) ${ }^{*}$, Halyna MISHCHUK (D)2, Iryna ROSHCHYK ${ }^{(2)}$, Olena JOSHI (i) 3 \\ ${ }^{1}$ Alexander Dubcek University of Trencin, Trencin, Slovakia \\ ${ }^{1}$ Sumy State University, Sumy, Ukraine \\ ${ }^{2}$ Department of Human Resources and Entrepreneurship, \\ National University of Water and Environmental Engineering, Rivne, Ukraine \\ ${ }^{3}$ Department of Computer Technologies and Economic Cybernetics, \\ National University of Water and Environmental Engineering, Rivne, Ukraine
}

Received 18 May 2020; accepted 7 July 2020

\begin{abstract}
The ability to attract and retain the talents is an important factor in the competitiveness of countries, as it is confirmed in our study. At the level of small and medium-sized enterprises, hiring and retaining skilled workers is one of the most difficult tasks of HR management, especially in transition economies with a high intensity of "leaching out" the skilled workers due to labour migration. Our research in Ukraine, which is a prime example of such countries, conducted via the cluster analysis allows us to conclude that the problems of hiring and retaining skilled workers have some connection with profitability: there is almost always a problem with filling vacancies with people of all educational levels in unprofitable enterprises, which is not typical of profitable businesses. The main problems with filling vacancies according to employers' estimations are: 1) market factors - shortage of employees with the required skills; 2) internal problems of ensuring the attractiveness of jobs (material - pay, and intangible - career prospects, flexible working hours, legal employment); 3) internal factors of inefficient HR management, including recruiting; 4) psycho-physiological factors of job satisfaction. However, there are no close links between the factors of hiring effectiveness and retention of skilled workers with the economic success of the organization in the form of the growth of assets, revenues and stuff. This leads to the conclusion that the practices of human resources management in small and medium-sized businesses in Ukraine are largely built chaotic, without analyzing the impact on the efficiency of the use of other resources and without providing links with the overall economic efficiency of enterprises.
\end{abstract}

Keywords: human resource, organizational economic success, SMEs, hiring, retention, vacancies.

JEL Classification: J23, J63, M51.

\section{Introduction}

Attracting and retaining talent is a recognized determinant of business competitiveness, which at the global level is one of the factors of economic success of countries in GTCI, the Global Competitiveness Index (INSEAD, 2018, 2019). Studying the relationship between the factors of hiring and retaining skilled workers in the HR management system of an enterprise is important not only in the context of traditional efforts to accumulate and develop human capital. The prerequisite for the success of such actions is the proper organizational support of HR processes, the adaptation of the internal components of the personnel management system to the external environment of the enterprise functioning, especially changes in the labour market. Given that small and medium-sized enterprises are most sensitive to such changes, research into the interrelationships of human resource practices and the economic success of businesses is an important and ongoing challenge. These are SMEs that, as a mobile business segment, largely determine changes in the labour market, both quantitatively and qualitatively, through changes in supply and demand for labour, as well as the activation of entrepreneurial potential in the development of new activities.

${ }^{*}$ Corresponding author. E-mail: yuriy_bilan@yahoo.co.uk

Copyright $\odot 2020$ The Author(s). Published by Vilnius Gediminas Technical University

This is an Open Access article distributed under the terms of the Creative Commons Attribution License (http://creativecommons.org/licenses/by/4.0/), which permits unrestricted use, distribution, and reproduction in any medium, provided the original author and source are credited. 
The problem of assessing the relationship between human capital of enterprises and economic success in various forms (performance, competitiveness, increasing market share, etc.) is not new to the theory and practice of personnel management. However, the dominant vector of such studies is the assessment of the impact of existing human capital in firms (Andersén, 2019; Chitsaz et al., 2019). In the context of our study, interesting conclusions about the impact of human capital on performance were obtained not only on the example of large enterprises, but also on small and micro-enterprises (Díaz-Chao et al., 2016; Khan \& Quaddus, 2018).

In all cases, studying the impact of human capital on the performance and competitiveness of enterprises, there were confirmed the positive links between investments in employee education, the accumulation of intellectual capital in various ways - from attracting from the outside environment to creating their own educational opportunities. At the same time, some researchers have even studied such an unexpected aspect as the ability of employees to "unlearning" and its impact on performance (Ruíz et al., 2017).

In any case, research on the relationship between human capital and the economic efficiency of enterprises mainly focuses on the ability to accumulate and use human capital in the form of knowledge, skills, adaptability to change. At the same time, there are even discussions about which term is more appropriate at the level of the organization - personnel management or human resources. In response, we can agree with the thesis that "HRM is now more concerned with business strategy and how to integrate HRM in the total optimization process of the firm" (Westeren, 2018, p. 1708).

The emphasis on the useful use of knowledge and their search in the market environment somewhat reduces the value of another component of successful HRM - a set of actions for recruiting and further creating a holistic system to meet the needs of skilled workers so that they not only maintain loyalty to the company but also work hard in favour of the overall growth of performance of the organization. Such studies are rare, especially for small and medium-sized enterprises, which largely determine the stability of local labour markets while maintaining macroeconomic competitiveness and security. This requires more attention to assessing the effectiveness of hiring and retaining skilled employees in terms of relationships with the performance of organizations.

With this in mind, our study aims to evaluate the effectiveness of existing HR practices in small and mediumsized enterprises in hiring and retaining skilled workers, and to look for links to the economic success of their business. The goal is pursued through the following research objectives: (1) assessing the link between economic performance and efforts to attract and retain talent at the macroeconomic level (through an analysis of relevant factors outlined in the Global Talent Competitiveness Report); (2) search for similar relationships, including through the analysis of HR management practices, at the enterprise level, using the results of our own sociological poll.

To accomplish Task 1, we use the traditional statistical analysis methodology with finding correlating links of factors. Task 2 was solved using the methodological toolkit available in Statistica software (for cluster analysis of human resource management problems in relation to organizational success), EViews (for assessing the impact of selected human resource management factors on enterprise profitability), MS Excel - for intermediate calculations, and groupings, as well as procedures for checking the statistical significance of relationships and variation analysis of the relationships of factors.

The limitation of the methodological nature, which created certain difficulties in processing information, was the problem of the biased presentation of information in the business environment regarding the true results of its activities. In Ukraine, on the basis of which the study was conducted, this problem is widespread (Mishchuk et al., 2020). However, subjectivity, which is always characteristic of the method of sociological surveys, and the possible lack of objective reflection of the true results of the activity could not significantly affect the findings obtained, which we confirmed in the estimates of the sample representativeness.

\section{Literature review}

The study of the components of personnel management systems at enterprises is carried out in many directions today. In most cases, such assessments are based on an analysis of the actual properties of the HR management system at the time of the research, and therefore include various components of $\mathrm{HR}$ practices that are important in terms of research on a particular outcome.

Thus, by evaluating the impact on enterprise performance, empirical evidence of the impact of efforts to create the intellectual capital of enterprises combined with such components as human capital, structural capital, relational capital (Urban \& Joubert, 2017) is obtained. Similar findings were obtained by Chitsaz et al. (2019) on the analysis of the factors of knowledge, skills, and selfefficacy within human capital and their impact on the rate of entrepreneurship activities and national gross product in some countries.

By examining entrepreneurial success as a subjective relative assessment of such success, Unger et al. (2011) have shown that, among the areas of high-value personnel management, the success of a company is influenced by the processes of learning, knowledge acquisition, and the transfer of knowledge. Entrepreneurial success is often expressed in the form of subjective perception. This metric, along with the level of productivity, is exemplified by a sample of small and medium-sized enterprises specializing in the field of renewable energy in order to evaluate relationships with human capital factors such as network ties, trust in network, shared vision, education 
and experience (Yadav et al., 2018); entrepreneurship education is also considered as important factor of success by Akimov et al. (2020). The economic and non-financial claims of businesses may also be reflected in other business results obtained through the proper management of personnel, including the stages of attracting and hiring. Such results include, e.g. the employer's brand and related market advantages (Carpentier et al., 2019; Green, 2019; Urbancová \& Hudáková, 2017), as well as the achievement of strategic goals of enterprises (Clinton, 2016; Sohel-UzZaman et al., 2019).

In doing so, it is important to consider the role of human resource management within strategic agility (Ahammad et al., 2020), firm scale and ability to attract talents (Moayedfar \& Madani Chafi, 2019) as well as the intention and aspirations of entrepreneurs themselves to succeed through the intensive use of human capital, including their own (Lee, 2019), gender and educational status of SMEs' executives regarding to entrepreneurial orientation (Ključnikov et al., 2019).

The success of the enterprise is viewed by other researchers through the self-assessment of the entrepreneur's success. Thus, the criteria for evaluating success are often the entrepreneurs' self-esteem based on the assessment of financial situation and the success of managers' perceptions relative to competitors (Baranowska-Prokop \& Sikora, 2017; Bondarenko et al., 2018; Kramoliš et al., 2020). Other criteria that indirectly characterize economic success include, e.g. the length of time a business operates on the market. In particular, in empirical studies of entrepreneurial success factors, Makhbul and Hasun (2011) have confirmed the greatest importance of such factors as the ability of entrepreneurs to access information, their leadership styles, and their support from others. At the same time, as in some other well-known studies in the field of entrepreneurial success, researchers believe that only those enterprises are successful that have been "operating for at least three years" (Makhbul \& Hasun, 2011, p. 117).

The factors of hiring and retaining skilled workers at enterprises are very often considered in the system of relationships with the economic success of enterprises not literally, but indirectly - by measuring employees' satisfaction with the quality of the entire HR management system or its individual components (Grishnova et al., 2019; Maamari \& Alameh, 2016; Mishchuk et al., 2016), including for certain categories of employees - senior workers, foreigners, women, etc. (Heywood \& Jirjahn, 2016; Hipp, 2020; Richardson, 2016), the use of corporate social responsibility (Gallardo-Vázquez \& Lizcano-Álvarez, 2020; Oliinyk, 2017) and social dialogue tools (S. Bilan et al., 2020a).

Thus, the theoretical basis for analyzing entrepreneurial success through the factors of quality management personnel today includes many concepts of factor analysis, which largely depend on the objectives of the study - the impact of the entire human resource management system or only its fragments that are the most relevant for some reason, including the holistic perception of needs satisfaction (Mishchuk et al., 2019). The results of such studies are always somehow or other related to the success rate of businesses. It makes both future opportunities to improve HR-management and further development of the enterprise dependant on it. Taking this into account, the choice of factors for own research will focus on improving the system of factors for attracting and retaining skilled workers, which are based on surveys of entrepreneurs while comparing global competitiveness trends (INSEAD, 2018, 2019). And the indicators that will be taken as results that illustrate entrepreneurial success need to be refined, considering existing approaches to their identification.

As it was mentioned above, such indicators include self-assessment of entrepreneurial success, the duration of business activities (as a certain indicator of viability), the achievement of strategic goals, and other subjective or indirect performance indicators.

At the same time, for our own research we consider such indicators more reasonable that, firstly, more clearly characterize the quantitative side of the success of enterprises, and therefore are less debatable and allow forming a comparable base of comparisons. Secondly, such indicators for comparisons of micro- and macro-level character should be comparable with the indicators used today in the system of national accounts and statistics of economic activities of enterprises.

Such indicators recognized in both statistical reporting and scientific literature are: firm performance (Horvathova \& Mokrisova, 2020; Lee, 2019; Yousuf et al., 2019; Zhu et al., 2019), revenue or a firm's growth, personal wealth creation, profitability, sustainability, turnover (Dafna, 2008; Perren, 2000; Narkunienè \& Ulbinaitė, 2018; Watson et al., 1998). Given that we will also conduct comparisons at the macro level, typical performance measures in the form of total and factor productivity (labour productivity) and other partial indicators of employment growth will be used as business performance, which is justified in (Y. Bilan et al., 2020b). At the same time, HR management performance indicators, which accumulate at the level of the national economy and generally characterize the ability to retain and attract skilled labour, are today methodologically best justified in GTCI in the form of Brain gain and Brain retention factors (INSEAD, 2018, 2019).

\section{Methodology}

We evaluated the efficiency of human resource practices in hiring and retention of skilled employees at two levels macroeconomic and enterprise level.

For the macroeconomic conclusions regarding the effectiveness of HR management in attracting and retaining talent, hypothesis $H 1$ has been suggested for the significant influence of retention and engagement factors of talent (skilled workers) on economic performance. 
To justify this hypothesis, we select the factors Brain gain and Brain retention, respectively, as reported in the Global Talent Competitiveness Report (INSEAD, 2018, 2019) and determined by different approaches to their numerical expression:

$x_{1}$ - Brain gain value $(1=$ country doesn't attract talented people from abroad; $7=$ country attracts to a great extent the best and brightest from around the world);

$x_{2}-$ Brain gain score $(0=$ country doesn 't attract talented people from abroad; $100=$ country attracts to a great extent the best and brightest from around the world);

$x_{3}$ - Brain retention value $(1=$ country doesn't retain talented people - the best and brightest leave to pursue opportunities abroad; 7 = country retains to a great extent - the best and brightest stay and pursue opportunities in the country);

$x_{4}-$ Brain retention score $(0=$ country doesn't retain talented people - the best and brightest leave to pursue opportunities abroad; $100=$ country retains to a great extent - the best and brightest stay and pursue opportunities in the country).

As resulting indicators of the impact of these factors, we selected cumulative indicators of individual economic success of the enterprises of EU countries (EU-28 countries), economic activities "Total business economy; repair of computers, personal and household goods; except financial and insurance activities", available in the relevant statistical databases (Eurostat, 2020a, 2020b):

$y_{1}$ - Turnover or gross premiums written (million euro);

$y_{2}-$ Gross operating surplus (million euro);

$y_{3}$ - Employees (number);

$y_{4}$ - Apparent labour productivity (Gross value added per person employed, in thousand euro);

$y_{5}$ - Gross fixed capital formation (current prices, million euro).

To estimate the impact, we calculate the percentage change (increase/decrease) of above mentioned factors and results in final year to previous (initial) one:

$$
\% \text { change }=\frac{\text { final }- \text { initial }}{\text { initial }} \times 100 \text {, }
$$

where increase is a positive percentage change, decrease is a negative percentage change.

The connection is verified by a correlation method based on a built-in function in MS Excel (PEARSON (Array1; Array2)) with a calculation of Pearson correlation coefficient:

$$
r=\frac{n\left(\sum x y\right)-\left(\sum x\right)\left(\sum y\right)}{\sqrt{\left[n \sum x^{2}-\left(\sum x\right)^{2}\right]\left[n \sum y^{2}-\left(\sum y\right)^{2}\right]}} .
$$

Values are interpreted using the scale given in (Hussin et al., 2014; Babiarz et al., 2020, p. 88).

T-test also called as Student's T-test was used as statistical significance test of Pearson correlation coefficient:

$$
t=\frac{r \sqrt{n-2}}{\sqrt{1-r^{2}}},
$$

where $n$ is the number of observations, $r$ is a correlation coefficient.

At the enterprise level, we conducted our own sociological survey to assess the impact of the effectiveness of attempts regarding hiring and retaining of skilled employees. The study was conducted on the example of one of the regional centers of Ukraine (Rivne), which belongs to the cross-border region with high migration and entrepreneurial activity, and HR management practices should therefore be sufficiently flexible. The survey embraced 526 respondents, including 170 business owners. The survey was conducted in June-September 2018.

Given the Cochran formula (Cochran, 1977), it can be argued that this sample size provides the level of precision at the level of $7.3 \%$ and $4,2 \%$ :

$$
n=\frac{z^{2} p(1-p) N}{z^{2} p(1-p)+N e^{2}},
$$

where $n$ is sample size (526 employees, incl. 170 business owners), $N$ - population size (13 570 employees, 2746 SMEs - according to the data of the State Statistics Service of Ukraine for the region in which the survey was conducted); $z$ - standard normal variable ( $z=1.96$ at $95 \%$ confidence level), $p-$ proportion or degree of variability $=$ $50 \%, e-$ the level of precision.

We used indicators in the form of turnover growth, total asset value, number of employees, productivity, and profitability as indicators of entrepreneurial successes that are subject to validation, similar to the scholars' previous arguments (Dafna, 2008; Lee, 2019; Perren, 2000; Narkunienè \& Ulbinaite, 2018; Watson et al., 1998).

Therefore, the following hypotheses were tested at the enterprise level:

$\mathrm{H} 2$ - problems with filling vacancies in enterprises that have become widespread in the local labour market are caused not so much by market factors as by the lack of the effectiveness of actions in the HR management system;

H3 - effective HR practices to attract and retain skilled workers have a positive impact on the enterprise's economic success.

The identification of the variables (factor and result) that were used to find relationships is presented in Table 1. Var1-Var21 variables characterize the HR management areas of small and medium-sized enterprises, and Var22Var27 variables - the economic success of business activities.

The search for relationships between the selected variables (Table 1) was implemented using the method of cluster analysis, the main purpose of which is to divide the set of objects and features under study into homogeneous in the appropriate sense of the group or cluster. This method was chosen because of its advantages, the main of which in our case is the ability to group objects not 
by one parameter, but by a set of features. In addition, cluster analysis, unlike most mathematical and statistical methods, does not impose any restrictions on the type of objects under study, and allows considering a set of source data of almost arbitrary nature. After all, in our case, the

Table 1. Identification of variables to reveal the effectiveness of actions as to attracting and retaining skilled workers, as well as the economic success of enterprises (source: developed by the authors)

\begin{tabular}{|c|c|c|}
\hline Variables & Description & Answer options \\
\hline Var1 & \multirow{3}{*}{$\begin{array}{l}\text { Success of efforts } \\
\text { to, } \%\end{array}$} & $\begin{array}{l}\text { attract skilled workers to the } \\
\text { enterprise }\end{array}$ \\
\hline Var2 & & $\begin{array}{l}\text { retain skilled workers in the } \\
\text { enterprise }\end{array}$ \\
\hline Var3 & & $\begin{array}{l}\text { socially protect the employees } \\
\text { of the enterprise }\end{array}$ \\
\hline Var4 & \multirow{3}{*}{$\begin{array}{l}\text { Problems with } \\
\text { filling vacancies } \\
\text { with higher } \\
\text { education }\end{array}$} & always \\
\hline Var5 & & often \\
\hline Var6 & & never \\
\hline Var7 & \multirow{3}{*}{$\begin{array}{l}\text { Problems with } \\
\text { filling vacancies } \\
\text { with post-secon- } \\
\text { dary education }\end{array}$} & always \\
\hline Var8 & & often \\
\hline Var9 & & never \\
\hline Var10 & \multirow{3}{*}{$\begin{array}{l}\text { Problems with } \\
\text { filling vacancies } \\
\text { with secondary } \\
\text { education }\end{array}$} & always \\
\hline Var11 & & often \\
\hline Var12 & & never \\
\hline Var13 & \multirow{9}{*}{$\begin{array}{l}\text { Problems with } \\
\text { filling vacancies, } \\
\text { in points }\end{array}$} & $\begin{array}{l}\text { There are few or no candidates } \\
\text { who have the required skills, } \\
\text { experience and potential }\end{array}$ \\
\hline Var14 & & $\begin{array}{l}\text { Vacancies are not related to } \\
\text { "official" employment }\end{array}$ \\
\hline Var15 & & $\begin{array}{l}\text { The work quality of the HR or } \\
\text { recruiting firm is poor }\end{array}$ \\
\hline Var16 & & $\begin{array}{l}\text { The offered salary and other } \\
\text { compensation are lower than } \\
\text { the candidates' wishes (mid- } \\
\text { market ones) }\end{array}$ \\
\hline Var17 & & $\begin{array}{l}\text { Career opportunities are } \\
\text { lacking or limited }\end{array}$ \\
\hline Var18 & & $\begin{array}{l}\text { Flexible scheduling or remote } \\
\text { work is lacking or limited }\end{array}$ \\
\hline Var19 & & $\begin{array}{l}\text { Working conditions cause } \\
\text { health problems }\end{array}$ \\
\hline Var20 & & $\begin{array}{l}\text { The psychological climate in } \\
\text { the team is characterized as } \\
\text { conflicting }\end{array}$ \\
\hline $\operatorname{Var} 21$ & & $\begin{array}{l}\text { The company's reputation } \\
\text { among consumers of products } \\
\text { is poor }\end{array}$ \\
\hline Var22 & \multirow{4}{*}{$\begin{array}{l}\text { Increase in } \\
\text { enterprise } \\
\text { performance, \% }\end{array}$} & volume of sales \\
\hline Var23 & & total value of assets \\
\hline Var24 & & the number of employees \\
\hline Var25 & & work efficiency \\
\hline Var26 & \multirow{2}{*}{$\begin{array}{l}\text { Profitability of } \\
\text { the enterprise }\end{array}$} & profitable \\
\hline Var27 & & unprofitable \\
\hline
\end{tabular}

indicators (Table 1) have different representations (quantitative data, qualitative data, fuzzy data) and correspond to different measurement scales (metric and non-metric), which complicates the application of traditional econometric approaches. In addition, taking into account that the original data is a sample of $n=170$ observations on $m=27$ features, it is the cluster analysis that allows considering this large amount of information and reducing it significantly, compressing a large array of socio-economic information, making it compact and clear.

In addition, cluster analysis can be used cyclically, which we used in the process of step-by-step elimination of variables that showed insignificant relationships with others. In this case, each cycle can provide information that can significantly change the direction and approaches to its further application. The results of the cyclical application of the cluster analysis methodology are given below in Section 3. Empirical findings.

At the same time, we also took into account that in the issues of socio-economic modelling of the influence of factors, cluster analysis is quite well combined with other quantitative methods, such as correlation-regression analysis.

It is the method of correlation-regression analysis that was used to further identify the relationship between variables that were previously analyzed by the cluster method. Correlation analysis, like other statistical methods, is based on the use of probabilistic models that allow describing the behaviour of indicators in some general totality, from which the studied values are obtained.

Among the variables selected for the study, there are discrete variables, i.e. the fact of the presence or absence of a feature in the i-th observation is indexed by the numbers 1 (presence of a feature) and 0 (absence of a feature). Therefore, when constructing mathematical models, the following were chosen, which are based on the functions of the standard normal distribution $N(0.1)$ (Probit model) and the functions of the standard logistics distribution (Logit model).

The implementation of the methods selected for the study was carried out using the software products of Statistica (for cluster analysis of human recourse management issues in relation to organizational success), EViews (for assessing the parameters of Probit and Logit models and their verification to investigate the impact of selected human resource management factors on enterprise profitability), MS Excel - for the grouping of actors, checking the statistical significance of relationships, as well as variation analysis and correlation relationships of factors.

\section{Empirical findings}

At the macroeconomic level, the following results of interaction of factors and economic success of business activities are established (Table 2).

It follows from Table 2 that the increase in the efficiency of attracting talents $\left(x_{1}, x_{2}\right)$ strongly influences 
Table 2. Correlation coefficients of enterprise economic success and HR management effectiveness in attracting and retaining talent in the EU (statistically significant correlation coefficients are italicized) (source: developed by the authors)

\begin{tabular}{|c|c|c|c|c|}
\hline \multirow{2}{*}{$\begin{array}{c}\text { Indicators } \\
\text { of economic } \\
\text { success of } \\
\text { enterprises }\end{array}$} & \multicolumn{4}{|c|}{$\begin{array}{c}\text { Performance indicators of HR management in } \\
\text { attracting and retaining talent }\end{array}$} \\
\cline { 2 - 5 } & $x_{1}$ & $x_{2}$ & $x_{3}$ & $x_{4}$ \\
\hline$y_{1}$ & 0.137 & 0.163 & 0.315 & 0.286 \\
\hline$y_{2}$ & 0.017 & 0.047 & 0.150 & 0.168 \\
\hline$y_{3}$ & 0.447 & 0,466 & 0.310 & 0.241 \\
\hline$y_{4}$ & -0.166 & -0.103 & 0.159 & 0.203 \\
\hline$y_{5}$ & 0.395 & 0.498 & 0.280 & 0.359 \\
\hline
\end{tabular}

such economic results as the increase in the number of employees and the value of fixed assets of enterprises $\left(y_{3}\right.$, $y_{5}$ ). According to the relevant recommendations (Babiarz et al., 2020; Hussin et al., 2014), such a relation is estimated as average - within the correlation coefficient values of $0.4-0.59$. In terms of talent retention $\left(x_{3}, x_{4}\right)$, the correlation relationships with the results are somewhat lower and insufficient to conclude that there are significant or even moderate relationships. The tightest among them (close to the lower boundary of the average bond strength) is the impact of talent retention on the growth of fixed assets of enterprises. Weak, but positive, links to such efforts are found in the growth of business turnover $\left(y_{1}\right)$.

As we can see, according to statistics on talent retention and involvement and their impact on the economic performance of enterprises in EU countries, hypothesis N1 can be partially confirmed. The impact of efforts to attract and retain talent is thus not strong enough, as it was expected, but some of the relationships are of medium-strength, and are therefore important to operate them for higher economic results, as it was confirmed in other studies (Y. Bilan et al., 2020b).

Therefore, after the partial confirmation of the $\mathrm{H} 1$ hypothesis at EU level, it is necessary to detail the reasons that may provoke insufficient links between the effectiveness of HR management and the economic success of enterprises, which is the task envisaged to test the $\mathrm{H} 2$ hypothesis.

This study was carried out by means of cluster analysis using Statistica. Figure 1 shows the constructed dendrogram for all 27 variables, the self-assessment to which was collected during the sociological survey.

As it can be seen from the figure, the group of factors most closely monitored in the global competitiveness report (Var 1-2) and the factor that may affect them (we introduced it for an additional analysis - Var 3) are not sufficiently related to other variables. The same conclusion is made on the basis of the correlation matrix analysis (Figure 2).

We can therefore state that in the sample of enterprises surveyed, efforts to retain and attract skilled workers have not yet become an attribute of management aimed at increasing the overall competitiveness of enterprises - such efforts are so far unrelated to the variables characterizing output / economic successes (Var 22-27).

Further analysis consisted in step-by-step elimination of variables that, by the results of correlation and cluster analysis, did not have sufficiently significant links to the results and other groups of problems that were grouped in certain clusters. This made it possible to obtain the following classes of problems in hiring skilled workers in terms of economic profitability in the form of business profitability - Var 26-27 (Figure 3).

Tree diagram for variables

Ward's method

Euclidean distances

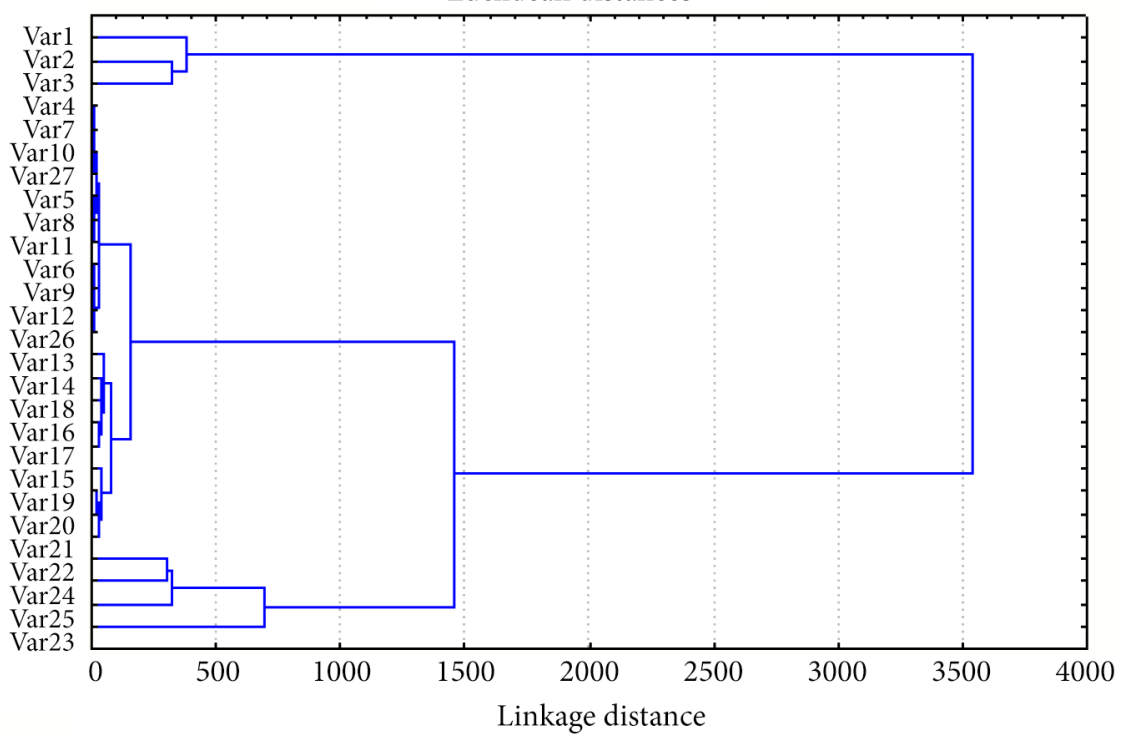

Figure 1. Dendrogram for Var1 - Var27 variables (source: developed by the authors) 
The results of the analysis allow us to draw the following conclusions within the framework of the $\mathrm{H} 2$ hypothesis testing. Problems with filling vacancies can be divided into two groups in which problems are ranked as follows (the total rank is calculated as the sum of points on each question, given that the maximum score was 7):
Group 1 - Market and internal factors that determine the attractiveness of jobs in a competitive environment of employers:

- Subgroup 1.1 - market factors of labour supply

- Var13 (There are few or no candidates who have the required skills, experience and potential) - total rank $=689$

\begin{tabular}{|c|c|c|c|c|c|c|c|c|c|c|c|c|c|c|c|c|c|c|c|c|c|c|c|c|c|c|c|}
\hline & Varl & Var2 & Var3 & Var4 & Var5 & Var6 & Var7 & Var8 & Var9 & Var10 & Var11 & Var12 & Var13 & Var14 & Var15 & Var16 & Var17 & Var18 & Var19 & Var20 & $\operatorname{Var} 21$ & Var22 & Var23 & Var24 & $\operatorname{Var} 25$ & Var26 & Var27 \\
\hline Varl & 1 & & & & & & & & & & & & & & & & & & & & & & & & & & \\
\hline Var2 & 0.50 & 1 & & & & & & & & & & & & & & & & & & & & & & & & & \\
\hline Var3 & 0.37 & 0.57 & 1 & & & & & & & & & & & & & & & & & & & & & & & & \\
\hline Var4 & -0.06 & -0.07 & -0.05 & 1 & & & & & & & & & & & & & & & & & & & & & & & \\
\hline Var5 & -0.08 & -0.16 & -0.13 & -0.19 & 1 & & & & & & & & & & & & & & & & & & & & & & \\
\hline Var6 & 0.10 & 0.18 & 0.14 & -0.29 & -0.87 & 1 & & & & & & & & & & & & & & & & & & & & & \\
\hline Var7 & -0.04 & -0.10 & -0.11 & 0.28 & -0.07 & -0.06 & 1 & & & & & & & & & & & & & & & & & & & & \\
\hline Var8 & -0.18 & -0.29 & -0.19 & -0.06 & 0.37 & -0.32 & -0.16 & 1 & & & & & & & & & & & & & & & & & & & \\
\hline Var9 & 0.19 & 0.32 & 0.23 & -0.12 & -0.30 & 0.34 & -0.31 & -0.86 & 1 & & & & & & & & & & & & & & & & & & \\
\hline Var10 & 0.02 & -0.11 & -0.05 & 0.27 & -0.02 & -0.11 & 0.30 & 0.15 & -0.32 & 1 & & & & & & & & & & & & & & & & & \\
\hline Var11 & -0.15 & -0.24 & -0.15 & -0.08 & 0.26 & -0.21 & 0.06 & 0.60 & -0.60 & -0.17 & 1 & & & & & & & & & & & & & & & & \\
\hline Var12 & 0.11 & 0.27 & \begin{tabular}{|l|} 
\\
\end{tabular} & -0.09 & -0.24 & 0.27 & -0.23 & -0.65 & 0.73 & -0.45 & -0.79 & 1 & & & & & & & & & & & & & & & \\
\hline Var13 & -0.03 & -0.14 & -0.10 & 0.00 & 0.22 & -0.23 & 0.16 & 0.13 & -0.16 & 0.18 & 0.08 & -0.20 & 1 & & & & & & & & & & & & & & \\
\hline Var14 & -0.09 & -0.19 & -0.43 & -0.11 & 0.02 & 0.02 & 0.01 & 0.16 & -0.16 & 0.05 & 0.17 & -0.17 & 0.20 & 1 & & & & & & & & & & & & & \\
\hline Var15 & 0.08 & 0.00 & -0.01 & 0.08 & -0.04 & -0.03 & 0.03 & -0.08 & 0.09 & -0.12 & 0.01 & 0.04 & 0.13 & 0.07 & 1 & & & & & & & & & & & & \\
\hline Var16 & -0.26 & -0.41 & -0.34 & -0.06 & 0.23 & -0.19 & 0.06 & 0.28 & -0.29 & 0.07 & 0.23 & -0.24 & 0.27 & 0.16 & 0.18 & 1 & & & & & & & & & & & \\
\hline Var17 & -0.23 & -0.31 & -0.32 & 0.03 & 0.28 & -0.31 & $\mid-0.02$ & 0.19 & -0.16 & -0.10 & 0.14 & -0.06 & 0.09 & 0.16 & 0.28 & 0.52 & 1 & & & & & & & & & & \\
\hline Var18 & -0.07 & -0.16 & -0.12 & 0.03 & 0.23 & -0.25 & -0.03 & 0.17 & -0.15 & -0.10 & 0.21 & -0.11 & 0.24 & 0.11 & 0.13 & 0.21 & 0.32 & 1 & & & & & & & & & \\
\hline Var19 & -0.08 & \begin{tabular}{|l|}
-0.18 \\
\end{tabular} & -0.07 & -0.11 & -0.06 & 0.08 & -0.15 & 0.06 & 0.01 & -0.11 & \begin{tabular}{|l|}
0.06 \\
\end{tabular} & 0.02 & -0.11 & 0.20 & \begin{tabular}{|l|}
0.27 \\
\end{tabular} & 0.08 & 0.07 & 0.17 & 1 & & & & & & & & \\
\hline Var20 & -0.06 & \begin{tabular}{|l|}
-0.13 \\
\end{tabular} & -0.11 & -0.02 & 0.00 & -0.04 & \begin{tabular}{|l|}
-0.08 \\
\end{tabular} & 0.00 & 0.03 & -0.15 & -0.04 & 0.14 & \begin{tabular}{|l|}
-0.04 \\
\end{tabular} & 0.11 & 0.22 & 0.10 & 0.20 & 0.34 & 0.58 & 1 & & & & & & & \\
\hline Var21 & -0.14 & -0.25 & -0.18 & -0.03 & 0.01 & -0.02 & 0.03 & -0.04 & 0.02 & -0.16 & 0.00 & 0.11 & 0.12 & 0.15 & 0.31 & 0.20 & 0.21 & 0.27 & 0.37 & 0.49 & 1 & & & & & & \\
\hline Var22 & 0.19 & 0.11 & 0.18 & -0.10 & -0.02 & 0.07 & -0.16 & -0.01 & 0.10 & 0.03 & -0.10 & 0.06 & 0.07 & -0.05 & $\mid-0.06$ & -0.20 & -0.11 & 0.07 & 0.08 & 0.15 & -0.01 & 1 & & & & & \\
\hline Var23 & -0.01 & 0.02 & 0.07 & 0.25 & -0.06 & -0.06 & -0.02 & 0.06 & -0.04 & -0.04 & -0.07 & 0.09 & -0.05 & -0.03 & 0.03 & -0.02 & -0.03 & -0.01 & 0.15 & 0.14 & 0.07 & 0.38 & 1 & & & & \\
\hline Var24 & 0.13 & 0.08 & 0.06 & -0.06 & 0.05 & -0.02 & -0.08 & -0.03 & 0.08 & -0.05 & -0.03 & 0.06 & -0.01 & 0.00 & 0.00 & -0.16 & -0.05 & 0.06 & 0.03 & 0.10 & 0.14 & 0.64 & 0.33 & 1 & & & \\
\hline Var25 & 0.05 & 0.11 & 0.16 & -0.10 & -0.04 & 0.07 & -0.17 & -0.13 & 0.21 & -0.08 & -0.19 & 0.22 & 0.05 & 0.01 & 0.01 & -0.16 & 0.02 & 0.07 & 0.10 & 0.14 & 0.19 & \begin{tabular}{|l|}
0.45 \\
\end{tabular} & 0.14 & 0.37 & 1 & & \\
\hline Var26 & 0.14 & 0.08 & \begin{tabular}{|l|}
0.07 \\
\end{tabular} & -0.24 & 0.14 & -0.02 & -0.26 & 0.11 & 0.06 & -0.10 & 0.01 & 0.05 & 0.09 & 0.18 & \begin{tabular}{|l|}
0.01 \\
\end{tabular} & -0.09 & 0.05 & 0.14 & 0.11 & -0.03 & -0.04 & 0.25 & 0.11 & 0.23 & 0.20 & 1 & \\
\hline Var27 & -0.14 & -0.08 & -0.07 & 0.24 & -0.14 & 0.02 & 0.26 & -0.11 & \begin{tabular}{|l|}
-0.06 \\
\end{tabular} & 0.10 & $\mid-0.01$ & -0.05 & \begin{tabular}{|l|}
-0.09 \\
\end{tabular} & -0.18 & $\mid-0.01$ & 0.09 & -0.05 & -0.14 & -0.11 & 0.03 & 0.04 & -0.25 & -0.11 & $\mid-0.23$ & -0.20 & -1.00 & 1 \\
\hline
\end{tabular}

Figure 2. Correlation matrix for Var1-Var27 variables (source: developed by the authors)

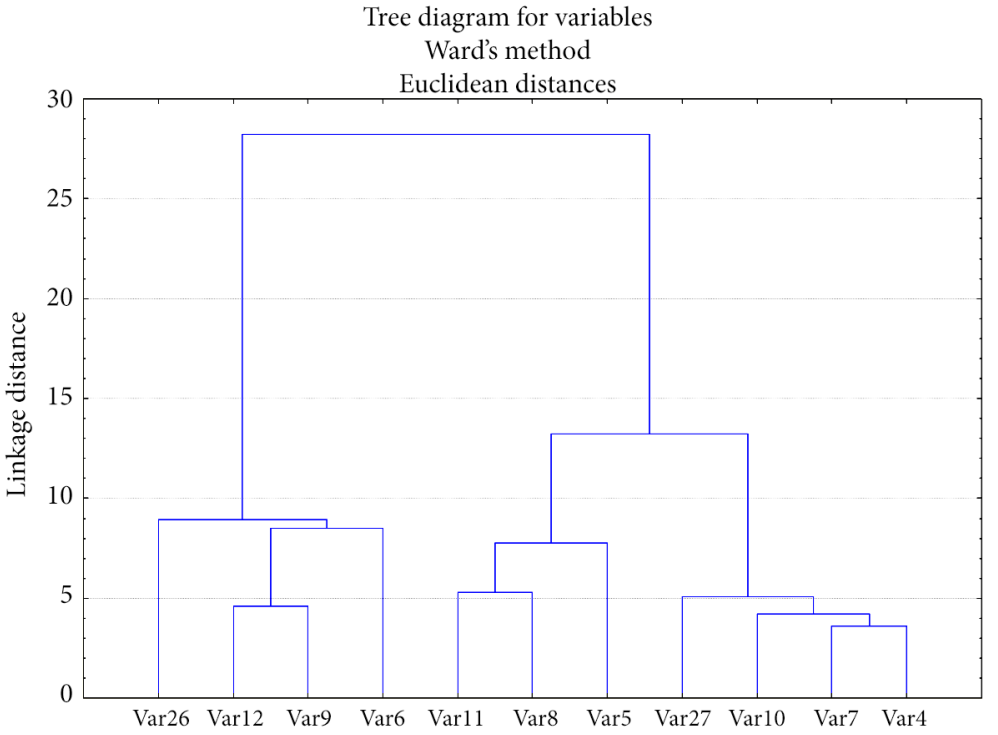

Figure 3. Dendrogram for the variables with the tightest bonds in HR management system in the surveyed enterprises in terms of profitability (source: developed by the authors) 
- Subgroup 1.2 - internal factors of attractiveness of workplaces

- Var16 (The offered salary and other compensation are lower than the candidates' wishes (mid-market ones) - total rank $=630$

- Var17 (Career opportunities are lacking or limited) total rank $=471$

- Var18 (Flexible scheduling or remote work is lacking or limited) - total rank $=406$

- Var14 (Vacancies are not related to "official" employment) - total rank $=330$

Group 2 - internal quality factors of HR-management and social responsibility of the enterprise, which determine the prospects of development of enterprise potential:

- Subgroup 2.1 - internal quality factors of HR-manager's work

- Var15 (The work quality of the HR or recruiting firm is poor) - total rank $=269$
- Subgroup 2.2 - psycho-physiological factors of job satisfaction

- Var19 (Working conditions cause health problems) - total rank $=208$

- Var20 (The psychological climate in the team is characterized as conflicting) - total rank $=196$

- Var21 (The company's reputation among consumers of products is poor) - total rank $=180$

Therefore, as it was expected, the problems of hiring and retaining skilled workers are more related to the internal factors behind the poor performance of HR management. Market factors, the influence of which is often explained by problems in filling vacancies in local labour markets, especially in cross-border regions, have not been as influential and widespread. The obtained links can therefore be interpreted as links with the reverse influence of the quality of personnel management in enterprises on the labour market: insufficient effectiveness of efforts

Table 3. Results of verification of the factors relationships (Var 1-3) to the profitability of business activities based on Logit and Probit models (source: developed by the authors)

\begin{tabular}{|c|c|c|c|c|c|c|c|c|c|}
\hline \multicolumn{5}{|c|}{ Logit-model } & \multicolumn{5}{|c|}{ Probit-model } \\
\hline \multicolumn{5}{|c|}{ Dependent Variable: $\mathrm{Y}$} & \multicolumn{5}{|c|}{ Dependent Variable: $\mathrm{Y}$} \\
\hline \multicolumn{5}{|c|}{ Method: ML - Binary Logit (Quadratic hill climbing) } & \multicolumn{5}{|c|}{ Method: ML - Binary Probit (Quadratic hill climbing) } \\
\hline \multicolumn{5}{|c|}{ Date: 02/05/20 Time: $20: 21$} & \multicolumn{5}{|c|}{ Date: 02/05/20 Time: 20:20 } \\
\hline \multicolumn{5}{|l|}{ Sample: 1170} & \multicolumn{5}{|c|}{ Sample: 1170} \\
\hline \multicolumn{5}{|c|}{ Included observations: 165} & \multicolumn{5}{|c|}{ Included observations: 165} \\
\hline \multicolumn{5}{|c|}{ Convergence achieved after 4 iterations } & \multicolumn{5}{|c|}{ Convergence achieved after 4 iterations } \\
\hline \multicolumn{5}{|c|}{ Covariance matrix computed using second derivatives } & \multicolumn{5}{|c|}{ Covariance matrix computed using second derivatives } \\
\hline Variable & Coefficient & Std. Error & z-Statistic & Prob. & Variable & Coefficient & Std. Error & z-Statistic & Prob. \\
\hline $\mathrm{X} 1$ & 0.002304 & 0.013395 & 0.171995 & 0.8634 & $\mathrm{X} 1$ & 0.001276 & 0.006373 & 0.200172 & 0.8413 \\
\hline $\mathrm{X} 2$ & 0.013872 & 0.014444 & 0.960434 & 0.3368 & $\mathrm{X} 2$ & 0.006837 & 0.007145 & 0.956951 & 0.3386 \\
\hline $\mathrm{X} 3$ & -0.000443 & 0.010545 & -0.042011 & 0.9665 & $\mathrm{X} 3$ & -0.000307 & 0.005407 & -0.056689 & 0.9548 \\
\hline $\mathrm{C}$ & 1.265194 & 0.701502 & 1.803550 & 0.0713 & $\mathrm{C}$ & 0.813246 & 0.370500 & 2.194994 & 0.0282 \\
\hline $\begin{array}{l}\text { McFadden } \\
\text { R-squared }\end{array}$ & 0.021460 & \multicolumn{2}{|c|}{ Mean dependent var } & 0.903030 & $\begin{array}{l}\text { McFadden } \\
\text { R-squared }\end{array}$ & 0.020655 & \multicolumn{2}{|c|}{ Mean dependent var } & 0.903030 \\
\hline $\begin{array}{l}\text { S.D. depen- } \\
\text { dent var }\end{array}$ & 0.296817 & \multicolumn{2}{|c|}{ S.E. of regression } & 0.296915 & $\begin{array}{l}\text { S.D. depen- } \\
\text { dent var }\end{array}$ & 0.296817 & \multicolumn{2}{|c|}{ S.E. of regression } & 0.297062 \\
\hline $\begin{array}{l}\text { Akaike info } \\
\text { criterion }\end{array}$ & 0.671566 & \multicolumn{2}{|c|}{ Sum squared resid } & 14.19357 & \begin{tabular}{|l}
$\begin{array}{l}\text { Akaike info } \\
\text { criterion }\end{array}$ \\
\end{tabular} & 0.672079 & \multicolumn{2}{|c|}{ Sum squared resid } & 14.20759 \\
\hline $\begin{array}{l}\text { Schwarz } \\
\text { criterion }\end{array}$ & 0.746862 & \multicolumn{2}{|c|}{ Log likelihood } & -51.40423 & $\begin{array}{l}\text { Schwarz } \\
\text { criterion }\end{array}$ & 0.747375 & \multicolumn{2}{|c|}{ Log likelihood } & -51.44656 \\
\hline $\begin{array}{l}\text { Hannan- } \\
\text { Quinn } \\
\text { criter. }\end{array}$ & 0.702132 & \multicolumn{2}{|l|}{ Deviance } & 102.8085 & $\begin{array}{l}\text { Hannan- } \\
\text { Quinn } \\
\text { criter. } \\
\end{array}$ & 0.702645 & \multicolumn{2}{|l|}{ Deviance } & 102.8931 \\
\hline $\begin{array}{l}\text { Restr. } \\
\text { deviance }\end{array}$ & 105.0632 & \multicolumn{2}{|c|}{ Restr. log likelihood } & -52.53158 & \begin{tabular}{|l|} 
Restr. \\
deviance
\end{tabular} & 105.0632 & \multicolumn{2}{|c|}{ Restr. log likelihood } & -52.53158 \\
\hline LR statistic & 2.254702 & \multicolumn{2}{|c|}{ Avg. log likelihood } & -0.311541 & LR statistic & 2.170054 & \multicolumn{2}{|c|}{ Avg. log likelihood } & -0.311797 \\
\hline $\begin{array}{l}\text { Prob (LR } \\
\text { statistic) }\end{array}$ & 0.521254 & & \begin{tabular}{|l|} 
Prob (LR \\
statistic)
\end{tabular} & 0.537871 & & & \\
\hline $\begin{array}{l}\text { Obs with } \\
\text { Dep }=0\end{array}$ & 16 & \multicolumn{2}{|l|}{ Total obs } & 165 & $\begin{array}{l}\text { Obs with } \\
\text { Dep = } 0\end{array}$ & 16 & Total & obs & 165 \\
\hline $\begin{array}{l}\text { Obs with } \\
\text { Dep }=1\end{array}$ & 149 & & & & $\begin{array}{l}\text { Obs with } \\
\text { Dep = } 1\end{array}$ & 149 & & & \\
\hline
\end{tabular}


to create an attractive workplace in all aspects (hygienic working conditions, psychological and economic motivational factors, organizational support for HR-processes) is either a "push" factor, or at least one that reduces the attractiveness of employment for existing jobs. This is the very reason for the formation of negative tendencies for the employment of skilled workers, not the objective reasons for the lack of a suitable job offer.

This conclusion can be confirmed by the results of testing the hypothesis $H 3$.

As it can be seen from Figure 3, there are always problems with filling enterprises with higher education (Var4), post-secondary education (Var7) and secondary education (Var10) at unprofitable enterprises (Var27). Conversely, profitable enterprises (Var26) have never had a problem filling vacancies with education of the appropriate level higher education (Var6), post-secondary education (Var9) and secondary education (Var12).

Meanwhile, such links are only fixed on results in the form of the profitability of enterprises. As for the other indicators of economic success we have analyzed in the form (Var 22-25), the belonging to a particular cluster is not recorded, as well as sufficiently dense correlation relationships in the constructed correlation matrix.

Further analysis of the relationship between the profitability of enterprises and the factors of recruitment and retention of skilled workers (Var 1-3) within the HR management systems created by enterprises (profitability of enterprises) also did not confirm the existence of significant influences for the use of such factors in economic modelling. Thus, using the EViews analysis package in the group of enterprises in which the respondents confirmed their profitable activities (Table 3 ), such relationships are not proved.

As it can be seen from the results of the audit, in the sample of enterprises, the factors of quality of retention and involvement of skilled personnel, including social protection instruments, do not have any impact on the positive financial results, which are obviously still achieved by other factors.

\section{Discussion}

Our research confirms slow development of effective human capital practices even in traditional directions of hiring and retaining of well-educated and skilled employees in transitive economy. At the same time, the well-known and typical efforts within the HRM activities aiming at attraction and retention of skilled workers, defined by other researches (Green, 2019, Maamari \& Alameh, 2016; Richardson, 2016), remain important for the success of hiring practices. They are connected with external market factors, but are mainly derived from internal effectiveness of HR policy, including social responsibility in workplaces and adjustment of appropriate working conditions. However, it still remains a problem how to connect successful hiring and retention activities within the framework of
HRM with overall management strategy aiming at market and financial success; at least it remains a practical problem in HRM in immature economies.

Analyzing this problem, it is necessary to take into account more meticulously the sectoral, regional features of HRM in terms of hiring and retaining employees of small and medium-sized enterprises, which are often due to sectoral and regional variations in shadowing and job costs.

In addition, to confirm whether the weak impact of recruitment and retention measures on the financial and economic performance of small and medium-sized enterprises should be linked to the immaturity of the economy, a similar study should be conducted in large organizations, where the level of profitability of operating activities and unit costs for personnel is higher, and turnover is lower.

Considering negative consequences and inappropriate attention of business owners to effective practices of personnel management in hiring and attraction of skilled employees, the further researches in transitive economies are necessary. Particularly, researches of social dialogue effectiveness, its dimensions in human resources development and retention should be developed via analysis of links with financial and other market consequences for enterprises. Combining researches of modern HRM trends with overall organisational success indicators can lead to useful implications for labour market policy makers; meanwhile, it can be a good evidence of importance and economic expediency of responsible personnel management policy for business owners.

\section{Conclusions}

According to the results of our research, we can draw the following conclusions. The competitiveness factors of enterprises formed within HR management systems have a recognized importance of influencing economic success proven by many studies. Such theoretical and empirical testing, which is regularly carried out on the example of enterprises of different activities, sizes and countries, today has numerous evidence that human capital can be an effective factor of economic success in the form of growth in sales revenue, enterprise assets, profits, expansion of its volume in the form of jobs increase. On the example of EU countries, we have confirmed certain patterns in the formation of positive economic results (most notably the increase in turnover and the value of fixed capital) on the basis of effective actions to attract and retain skilled workers.

The power of influence of such factors, however, may be ambiguous and have significant differences depending on the HR strategies chosen. Thus, in enterprises where HR-management strategies are implemented without a clear link with the analysis and management of factors of employment relations, the corresponding results of insufficient effectiveness of influence of quality of work with personnel on the economic results of enterprises are obtained. In the group of small and medium-sized 
enterprises, which theoretically should be the most mobile and flexible in the implementation of modern levers of human resources management, such connections have proved not sufficiently close. The main groups of problems of modern personnel management at such enterprises are mainly internal ones, related to inefficient organization of hiring, personnel development, organization of jobs and motivation. Accordingly, insufficient attention to the factors of personnel management was that the formerly redundant labour market had turned into a labour shortage with acute shortage of skilled labour. This is particularly noticeable for businesses that are unable to provide profitable activities through the use of other factors other than personnel. It is this group of businesses that faces the most significant problems with filling vacancies. However, the effectiveness of recruitment and retention efforts today has no significant link with economic performance other than profitability.

Comparing the results with other research in the field of study it should be noted that entrepreneurship in immature economy does not always reflect positive links between human capital factors and entrepreneurial success, as it was emphasized in some similar researches (Chitsaz et al., 2019; Westeren, 2018; Unger et al., 2011; Yadav et al., 2018). In the reviewed group of enterprises some similarities were obtained only in links with profitability.

Thus, our findings indicate that in the labour market of transition economies, where business owners do not have a clear orientation and build effective HR practices and high social responsibility to employees, personnel management processes are mostly chaotic, without a clear dependence on other business processes at enterprises. The persistence of such personnel behaviours prevents the use of well-established mechanisms of using HR factors as tools to enhance economic success. Moreover, such disagreements with the overall enterprise competitiveness management system have an even more dangerous external effect - the gradual leaching of the most skilled part of the human resources of the local labour market to the benefit of other regions and countries that cannot be quickly compensated, even under the influence of force majeure and the forced return of part of the Ukrainian migrant population under the conditions of pandemic.

\section{Acknowledgements}

The data used in this work were obtained in the process of a sociological study of the development of small and medium-sized enterprises on the compliance of employment with the criteria of decent work, commissioned by the Department of Economy of Rivne City Council in June - September 2018 (contract \# 3 of June 1, 2018).

This research was funded by the grants from the Ministry of Education and Science of Ukraine (No 0120U102002, No0120U102001).

This work was supported by the Slovak Research and Development Agency under the contract No. APVV-190579.

\section{References}

Ahammad, M. F., Glaister, K. W., \& Gomes, E. (2020). Strategic agility and human resource management. Human Resource Management Review, 30(1), 100700.

https://doi.org/10.1016/j.hrmr.2019.100700

Akimov, O., Karpa, M., Parkhomenko-Kutsevil, O., Kupriichuk, V., \& Omarov, A. (2020). Entrepreneurship education of the formation of the e-commerce managers professional qualities. Journal of Entrepreneurship Education, 23(S1).

Andersén, J. (2019). Resource orchestration of firm-specific human capital and firm performance - the role of collaborative human resource management and entrepreneurial orientation. The International Journal of Human Resource Management, 1-33. https://doi.org/10.1080/09585192.2019.1579250

Babiarz, P., Kamuda, D., \& Migała-Warchoł, A. (2020). Testing the Polish society security. Journal of International Studies, 13(1), 81-92. https://doi.org/10.14254/2071-8330.2020/13-1/5

Baranowska-Prokop, E., \& Sikora, T. (2017). Innovativeness and success perception of Polish small-and medium-sized international new ventures. Journal of International Studies, 10(3), 134-146. https://doi.org/10.14254/2071-8330.2017/10-3/10

Bilan, S., Mishchuk, H., Samoliuk, N. \& Ostasz, G. (2020a). Effectiveness of social dialogue in the system of sustainable economic development factors. Paper presented at the Proceedings of the 34th International Business Information Management Association Conference, IBIMA 2020: Vision 2025: Education Excellence and Management of Innovations through Sustainable Economic Competitive Advantage (pp. 13303-13313). Madrid, Spain.

Bilan, Y., Mishchuk, H., Roshchyk, I., \& Kmecova, I. (2020b). Analysis of intellectual potential and its impact on the social and economic development of European countries. Journal of Competitiveness, 1, 22-38.

https://doi.org/10.7441/joc.2020.01.02

Bondarenko, S., Liganenko, I., Kalaman, O., \& Niekrasova, L. (2018). Comparison of methods for determining the competitiveness of enterprises to determine market strategy. International Journal of Civil Engineering and Technology, 9(13), 890-898.

Carpentier, M., Van Hoye, G., \& Weijters, B. (2019). Attracting applicants through the organization's social media page: Signaling employer brand personality. Journal of Vocational Behavior, 115, 103326. https://doi.org/10.1016/j.jvb.2019.103326

Chitsaz, E., Tajpour, M., Hosseini, E., Khorram, H., \& Zorrieh, S. (2019). The effect of human and social capital on entrepreneurial activities: a case study of Iran and implications. Entrepreneurship and Sustainability Issues, 6(3), 1393-1403. https://doi.org/10.9770/jesi.2019.6.3(24)

Clinton, E. (2016). Human resources in the family businessmaximising the power of your people. The Irish Journal of Management, 35(2), 176-178.

https://doi.org/10.1515/ijm-2016-0014

Cochran, W. G. (1977). Sampling techniques (3rd ed.). John Wiley \& Sons.

Dafna, K. (2008). Managerial performance and business success: Gender differences in Canadian and Israeli entrepreneurs. Journal of Entreprising Communities: People and Places in the Global Economy, 2(4), 300-331. https://doi.org/10.1108/17506200810913890

Díaz-Chao, Á., Sainz-González, J., \& Torrent-Sellens, J. (2016). The competitiveness of small network-firm: A practical tool. Journal of Business Research, 69(5), 1769-1774. https://doi.org/10.1016/j.jbusres.2015.10.053 
Eurostat. (2020a). Annual enterprise statistics for special aggregates of activities (NACE Rev. 2): Turnover or gross premiums written. Gross operating surplus. Employees. Apparent labour productivity (Gross value added per person employed).

https://appsso.eurostat.ec.europa.eu/nui/show.do?dataset =sbs_na_sca_r2\&lang=en

Eurostat. (2020b). Gross fixed capital formation by AN_F6 asset type: current prices, million euro. http://appsso.eurostat. ec.europa.eu/nui/show.do?dataset=nama_10_an6\&lang=en

Gallardo-Vázquez, D., \& Lizcano-Álvarez, J. L. (2020). CSR-related competitiveness and legitimacy in MSMEs. Economics \& Sociology, 13(1), 52-73.

https://doi.org/10.14254/2071-789X.2020/13-1/4

Green, K. (2019). Competitive people strategy: how to attract, develop and retain the staff you need for business success. Kogan Page Publishers.

Grishnova, O., Cherkasov, A., \& Brintseva, O. (2019) Transition to a new economy: transformation trends in the field of income and salary functions. Problems and Perspectives in Management, 17(2), 18-31.

https://doi.org/10.21511/ppm.17(2).2019.02

Heywood, J. S., \& Jirjahn, U. (2016). The hiring and employment of older workers in Germany: A comparative perspective. Journal for Labour Market Research, 49(4), 349-366. https://doi.org/10.1007/s12651-015-0195-4

Hipp, L. (2020). Do hiring practices penalize women and benefit men for having children? Experimental evidence from Germany. European Sociological Review, 36(2), 250-264. https://doi.org/10.1093/esr/jcz056

Horvathova, J., \& Mokrisova, M. (2020). Business competitiveness, its financial and economic parameters. Montenegrin Journal of Economics, 16(1), 139-153. https://doi.org/10.14254/1800-5845/2020.16-1.9

Hussin, F., Ali, J., \& Noor, M. S. Z. (2014). Kaedah penyelidikan \& analisis data SPSS. Universiti Utara Malaysia Press.

INSEAD. (2018). The Global Talent Competitiveness Index 2018. Fontainebleau, France. https://www.insead.edu/sites/default/ files/assets/dept/globalindices/docs/GTCI-2018-report.pdf

INSEAD. (2019). The Global Talent Competitiveness Index 2019. Fontainebleau, France. https://www.insead.edu/sites/default/ files/assets/dept/globalindices/docs/GTCI-2019-Report.pdf.

Khan, E. A., \& Quaddus, M. (2018). Dimensions of human capital and firm performance: Micro-firm context. IIMB Management Review, 30(3), 229-241.

https://doi.org/10.1016/j.iimb.2018.05.004

Kramoliš, J., Šviráková, E., \& Král, D. (2020). Design management as crucial creative essence for business success in small and medium-sized enterprises. Creativity Studies, 13(1), 8798. https://doi.org/10.3846/cs.2020.9904

Ključnikov, A., Civelek, M., Čech, P., \& Kloudová, J. (2019). Entrepreneurial orientation of SMEs' executives in the comparative perspective for Czechia and Turkey. Oeconomia Copernicana, 10(4), 773-795. https://doi.org/10.24136/oc.2019.035

Lee, B. (2019). Human capital and labor: the effect of entrepreneur characteristics on venture success. International Journal of Entrepreneurial Behavior \& Research.

https://doi.org/10.1108/IJEBR-10-2017-0384

Makhbul, Z. M., \& Hasun, F. M. (2011). Entrepreneurial success: An exploratory study among entrepreneurs. International Journal of Business and Management, 6(1), 116. https://doi.org/10.5539/ijbm.v6n1p116

Maamari, B. E., \& Alameh, K. (2016). Talent management moderating the relationship between recruitment for the highly skilled and HR policies. Contemporary Management Research, 12(1), 121-138. https://doi.org/10.7903/cmr.14133

Mishchuk, H., Bilan, S., Yurchyk, H., Akimova, L., \& Navickas, M. (2020). Impact of the shadow economy on social safety: The experience of Ukraine. Economics and Sociology, 13(2), 284-298. https://doi.org/10.14254/2071-789X.2020/13-2/19

Mishchuk, H., Bilan, Y., \& Pavlushenko, L. (2016). Knowledge management systems: issues in enterprise human capital management implementation in transition economy. Polish Journal of Management Studies, 14(1), 163-173.

https://doi.org/10.17512/pjms.2016.14.1.15

Mishchuk, H., Samoliuk, N., \& Bilan, Y. (2019). Measuring social justice in the light of effectiveness of public distributive policy. Administration \& Public Management Review, 32, 63-76. https://doi.org/10.24818/amp/2019.32-05

Moayedfar, R., \& Madani Chafi, M. (2019). A theoretical expansion of talent allocation model: evidence from selected developing countries from 2014-2018. Entrepreneurial Business and Economics Review, 7(4), 57-72. https://doi.org/10.15678/EBER.2019.070404

Narkunienè, J., \& Ulbinaite, A. (2018). Comparative analysis of company performance evaluation methods, Entrepreneurship and Sustainability Issues, 6(1), 125-138. https://doi.org/10.9770/jesi.2018.6.1(10)

Oliinyk, O. O. (2017). Corporate social responsibility in the field of occupational safety and health. Scientific Bulletin of $\mathrm{Na}$ tional Mining University, 2, 128-133.

Perren, L. (2000). Factors in the growth of micro-entreprise: Exploring the implications. Journal of Small Business and Enterprise Development, 7(1), 58-68.

https://doi.org/10.1108/EUM0000000006805

Richardson, K. (2016). Attracting and retaining foreign highly skilled staff in times of global crisis: a case study of Vancouver, British Columbia's biotechnology sector. Population, Space and Place, 22(5), 428-440. https://doi.org/10.1002/psp.1912

Ruíz, M. D. A., Gutiérrez, J. O., Martínez-Caro, E., \& CegarraNavarro, J. G. (2017). Linking an unlearning context with firm performance through human capital. European Research on Management and Business Economics, 23(1), 16-22. https://doi.org/10.1016/j.iedeen.2016.07.001

Sohel-Uz-Zaman, A. S. M., Anjalin, U., \& Khan, R. I. (2019). Human capital management: understanding its implications over the business. International Journal of Economics, Finance and Management Sciences, 7(5), 170.

https://doi.org/10.11648/j.ijefm.20190705.13

Unger, J. M., Rauch, A., Frese, M., \& Rosenbusch, N. (2011). Human capital and entrepreneurial success: A meta-analytical review. Journal of Business Venturing, 26(3), 341-358.

https://doi.org/10.1016/j.jbusvent.2009.09.004

Urban, B., \& Joubert, G. C. D. S. (2017). Multidimensional and comparative study on intellectual capital and organisational performance. Journal of Business Economics and Management, 18(1), 84-99.

https://doi.org/10.3846/16111699.2016.1255990

Urbancová, H., \& Hudáková, M. (2017). Benefits of employer brand and the supporting trends. Economics \& Sociology, 10(4), 41-50. https://doi.org/10.14254/2071-789X.2017/10-4/4

Watson, K., Hogarth-Scott, S., \& Wilson, N. (1998). Small business start-ups: success factors and support implications. International Journal of Entrepreneurial Behavior \& Research, 4(3), 217-238. https://doi.org/10.1108/13552559810235510 
Westeren, K. I. (2018). Human capital management for the improvement of competitiveness in firms. In Operations and Service management: concepts, methodologies, tools, and applications (pp. 1708-1725). IGI Global. https://doi.org/10.4018/978-1-5225-3909-4.ch078

Yadav, M. P., Venkata, V. P. R. P., \& Pradhan, R. S. (2018). Impact of financial, social and human capital on entrepreneurial success. International Journal of Small Business and Entrepreneurship, 6(4), 1-28.

Yousuf, A., Haddad, H., Pakurar, M., Kozlovskyi, S., Mohylova, A., Shlapak, O., \& János, F. (2019). The effect of operational flexibility on performance: a field study on small and medium-sized industrial companies in Jordan. Montenegrin Journal of Economics, 15(1), 47-60.

https://doi.org/10.14254/1800-5845/2019.15-1.4

Zhu, Y., Yang, H., \& Bai, G. (2019). Relationship between staff competency and performance of service-oriented manufacturing enterprises in China. Transformations in Business \& Economics, 18(1), 234-248. 